\title{
GANGRENE OF THE FOREARM AFTER SUBCLAVIAN ARTERIO-AORTOSTOMY FOR COARCTATION OF THE AORTA
}

\author{
BY \\ C. FREDERICK KITTLE AND PAUL W. SCHAFER \\ From the Department of Surgery, the University of Kansas Medical Centre, Kansas City, Kansas
}

(RECEIVED FOR PUBLICATION FEBRUARY 25, 1953)

Utilization of the subclavian artery in establishing an anastomotic shunt between major portions of the cardiovascular system for application to congenital cardiovascular anomalies was first suggested by Blalock and Park (1944). Subsequently, its practicability has been demonstrated in uncounted instances, Blalock (1948) and Ravitch (1953) describing over 1,100 cases in which this procedure was used for treating the tetralogy of Fallot. Clagett (1947) first employed subclavian arterio-aortostomy in coarctation of the aorta. Other series discussing the use of subclavian shunts have been reported by Shumacker (1951), Gross (1945), and many others.

TABLE I

GANGRENE OF THE ARM AFTER SUBCLAVIANPULMONARY ARTERIO-ARTERIOSTOMY

\begin{tabular}{|c|c|c|c|}
\hline Author & Disease & $\begin{array}{c}\text { Age } \\
\text { (Yrs.) }\end{array}$ & Remarks \\
\hline $\begin{array}{l}\text { Webb and } \\
\text { Burford } \\
\text { (1952) }\end{array}$ & $\begin{array}{c}\text { Tetralogy } \\
\text { of Fallot }\end{array}$ & 1 & $\begin{array}{l}\text { Right posterolateral incision with } \\
\text { 4th rib resection. Internal } \\
\text { mammary, vertebral, costocervi- } \\
\text { cal, and thyrocervical arteries } \\
\text { ligated. End-to-side anastomosis } \\
\text { of subclavian to pulmonary } \\
\text { artery. Thrombosis of anastomo- } \\
\text { sis occurred post-operatively. } \\
\text { Gangrene of forearm; heparin } \\
\text { given without appreciable bene- } \\
\text { fit. Excellent discussion of } \\
\text { contributing factors }\end{array}$ \\
\hline $\begin{array}{l}\text { Hanlan and } \\
\text { Varco } \\
\text { (1952) }\end{array}$ & & 2 & $\begin{array}{l}\text { Right thoracotomy. Pre-operative- } \\
\text { ly, right radial pulse weaker than } \\
\text { left. Gangrene of lower third of } \\
\text { right forearm noted } 6 \text { hours after } \\
\text { surgery. Death occurred } 24 \\
\text { hours later. Child was believed } \\
\text { to have right-sided hemiatrophy }\end{array}$ \\
\hline $\begin{array}{l}\text { D'Allaines } \\
\text { (1950) }\end{array}$ & $"$ & $? ?$ & $\begin{array}{l}\text { Gangrene of entire arm developed } \\
\text { after anastomosis of left sub- } \\
\text { clavian to pulmonary artery. No } \\
\text { other details given }\end{array}$ \\
\hline Lam (1949) & $"$ & 5 & $\begin{array}{l}\text { Posterolateral thoracotomy. Inter- } \\
\text { nal mammary, vertebral, and } \\
\text { thyrocervical trunk ligated. } \\
\text { "Gangrene of the arm resulted } \\
\text { and the child expired" }\end{array}$ \\
\hline
\end{tabular}

That transection of the subclavian artery can be tolerated without manifest ischaemia of the upper extremity has been appreciated for many years, this clinical knowledge being particularly emphasized in the care of war injuries (DeBakey and Amspacher, 1949 ; DeBakey and Simeone, 1946). Gangrene of the arm after anastomosis of the subclavian and pulmonary arteries for the alleviation of Fallot's tetralogy has been cited in four patients (Table I). Gangrene of the arm following anastomosis of the subclavian artery to the descending aorta in the treatment of coarctation of the aorta is an extremely rare complication, no previous mention of it having been found in the medical literature.

\section{CAse RePort}

C. S., an 18-year-old boy entered the University of Kansas Medical Centre on December 15, 1949, for the investigation of mild exertional dyspnoea noted since birth, and attacks of dizziness and frontal headaches for three years. His dyspnoea was not accompanied by cyanosis and occurred after walking half a block. In December, 1948, he became unconscious while lifting a foot-locker. Subsequent physical examination disclosed a systolic blood pressure reported as $210 \mathrm{~mm}$. $\mathrm{Hg}$. He was admitted to hospital, and a diagnosis of malignant hypertension was made. In September, 1949, an entrance physical examination for college showed a blood pressure of $270 \mathrm{~mm}$. Hg. The diagnosis of aortic coarctation was established and surgical correction advised.

Examination of the patient revealed a welldeveloped, moderately obese, white male, appearing quite healthy. The head, neck, arms, and chest appeared ruddy and were warm to touch. The legs were pale and cool. Neither arterial pulsations nor a blood pressure could be obtained in the lower extremities. The heart was slightly enlarged to palpation along its left border. A harsh systolic murmur (Grade III) was heard over the aortic area without an accompanying thrill. Along the left border of the sternum, loudest at the second interspace, was a short diastolic murmur. The first heart sound was accentuated and duplicated. In the midscapular area 


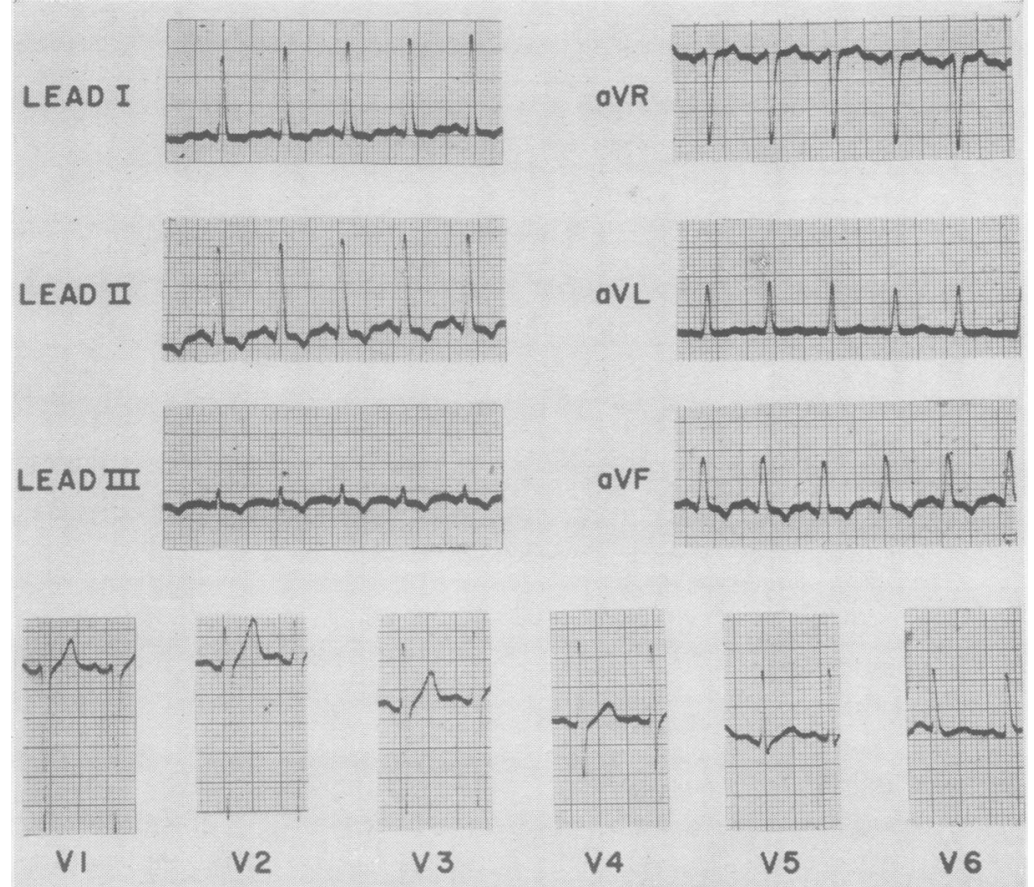

FIG. 1.-Electrocardiogram (standard leads, limb vectors, and chest leads) showing left ventricular hypertrophy and strain.

and along the inferior margins of the lower ribs anteriorly a loud systolic bruit was evident. The blood pressure in the right arm was $210 / 80 \mathrm{~mm}$. of $\mathrm{Hg}$; in the left, $190 / 70 \mathrm{~mm}$. of $\mathrm{Hg}$. The retinal arterioles were markedly tortuous and exhibited the "corkscrew" sinuous appearance described in this disease (Granström, 1951). No other significant abnormalities were found on physical examination.

Routine analysis of urine, a blood count, and the blood non-protein nitrogen, creatinine, fasting glucose, sodium chloride, and total serum protein were within normal limits. Electrocardiography revealed a slight left ventricular enlargement (Fig. 1). Radiographic studies disclosed enlargement of the left ventricle with a diminutive aortic knob. Serration of the neurovascular grooves of the ribs was noted posteriorly, involving the third to the ninth ribs on the left, and the third to the seventh on the right. Intravenous pyelography with diodrast visualized normal kidney architecture.

Because of the patient's obesity $(225 \mathrm{lb}$.) operation was not deemed advisable at this time. He was placed on a reducing diet and instructed to return at a later date. Readmission on May 2, 1950, disclosed the same physical signs (except for his weight) and laboratory findings. Further renal function tests revealed an effective blood flow of $920 \mathrm{ml}$. per minute; a tubular mass (glucose) of $420 \mathrm{mg}$. ; a plasma clearance (para-amino-hippuric acid excretion) of $368 \mathrm{ml}$. per minute ; a phenolsulphothalein excretion of $11 \%$ in 20 minutes, $58 \%$ in 30 .
Exploratory thoracotomy was done on May 13, 1950, with the patient in the lateral recumbent position. Using sodium pentothal induction an endotracheal tube was inserted and cyclopropane - oxygen anaesthesia, supplemented with intravenous curare, was administered. The thorax was opened, utilizing a Crafoord incision with subperiosteal resection of the left fifth rib. The mediastinal pleura was reflected from the descending aorta. This revealed a localized coarctation, almost directly opposite the ligamentum arteriosum. Gradual reduction and enlargement of the aorta proximally and distally for $1 \mathrm{~cm}$. was found with no evidence of any aneurysmal dilatation.

Collateral circulation around the coarctation was extremely prominent, being most noticeable in the internal mammary artery and its branches. Excision of the coarctation with direct endto-end anastomosis was not deemed possible, and accordingly, a subclavian arterioaortustomy, end-to-end, was planned. Mobilization of the subclavian artery was done, and to secure further length the thyrocervical axis and the costocervical branch were ligated and divided. The aorta was isolated distally by ligation and transection of the ligamentum arteriosum as well as the first three intercostal branches bilaterally. A Blalock clamp was applied to the subclavian artery proximally, and it was ligated distally with No. 2 braided silk reinforced with a suture of 000 silk, leaving the proximal end open. Bradshaw-O'Neil clamps were placed on each side of the coarctation and a $1-\mathrm{cm}$. segment of the aorta was excised. The aorta was closed on its proximal end with a continuous suture of 000 silk. The subclavian artery was then rotated downward and an end-to-end arterio-aortostomy done using interrupted everting mattress sutures of 0000 silk, buttressed by several interrupted sutures. This was accomplished without undue angulation, effecting an orifice of approximately $1.8 \mathrm{~cm}$. internal diameter (Figs. 2 and 3). The clamps were released distally, and then proximally. No cardiac irregularities were noted at any time during the operative procedure. The lung was re-expanded and the chest closed in anatomical layers.

Examination of the resected specimen revealed the usual type of "adult" coarctation with an irregular internal orifice of $0.15 \mathrm{~cm}$. Early atheromatous changes were found microscopically, particularly in the aortic wall distal to the coarctation.

On the day following operation the patient complained of coldness, numbness, and continuous aching 


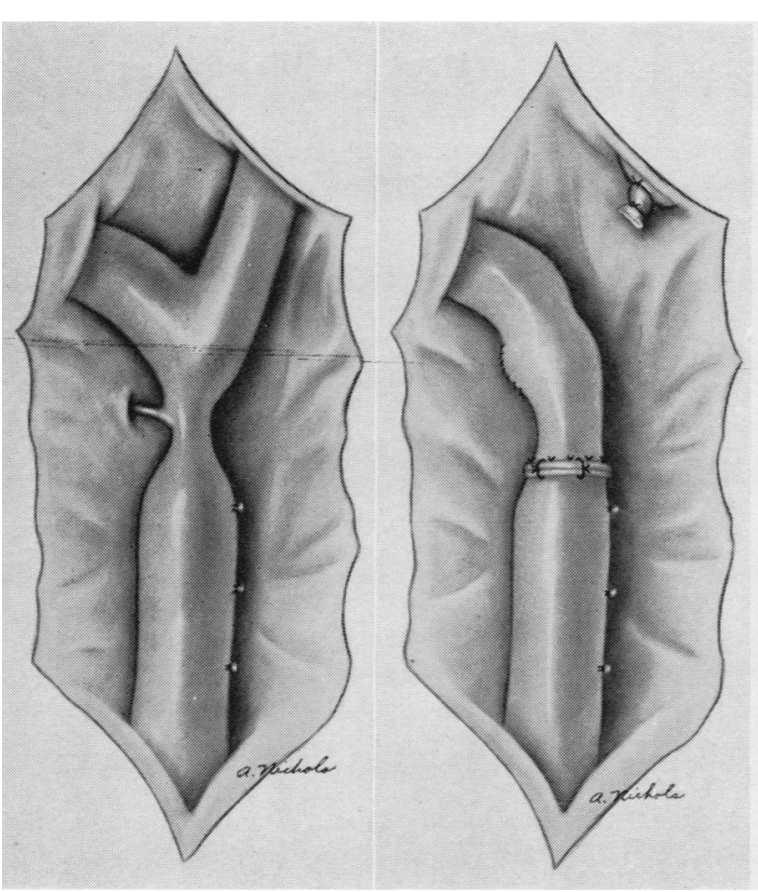

FIGS. 2 and 3.-Diagrammatic sketch of the operative field before and after resection of the coarcted segment of aorta.

throughout his left arm, only partially relieved by the usual doses of "dilaudid." By the third postoperative day he was unable to move his fingers, and procaine paravertebral sympathetic block in the region of the first to fourth thoracic segments was done on the left. The block was supplemented by alternately massaging his arm and packing it in ice. He was also given " priscol," 25 to $50 \mathrm{mg}$., four times daily. The initial block was maintained continuously by inserting a polythene catheter into the paravertebral area and injecting a $1 \%$ procaine solution with added penicillin at the rate of 40 to $60 \mathrm{ml}$. per hour. This was continued until the fifteenth postoperative day, when it was discontinued because of mental confusion, vertical nystagmus, and slight oedema of the optic discs. Following cessation of the procaine injections these symptoms disappeared. At this time the left arm was markedly oedematous from the elbow distally, the fingers were cyanotic, and numerous superficial bullae were present. The distal portion of the arm was cold. During the next two weeks the changes were less acute, but the fingertips became black and atrophic. An oedematous gangrene extended two-thirds of the distance to the elbow.

Amputation through the lower third of the arm was done on June 10, 1950. Examination of the resected forearm revealed gangrene with an organizing thrombosis of the radial and ulnar arteries. His recovery from this procedure was uneventful, and he was discharged from the hospital on June 19, 1950.
The blood pressures after repair of the coarctation varied between 160 and $190 \mathrm{~mm}$. of $\mathrm{Hg}$ systolic and 70 to $100 \mathrm{~mm}$. of $\mathrm{Hg}$ diastolic in the right arm. Segmental renal function studies done one month and eight months after thoracotomy showed no essential changes from those described pre-operatively.

The patient has been seen on several occasions in the out-patient clinic, the most recent being June, 1951. His blood pressure has persisted at its originally described levels. Although he continues to complain of the same type of headache that disturbed him before surgery, he attends college, carries a full school curriculum, and works outside school for his maintenance.

\section{Discussion}

That one patient develops gangrene of the arm following occlusion of the subslavian artery while another does not depends upon several factors. It is usually difficult to ascertain the most important factor in any particular case. Those most worthy of mention are the exact portion of the subclavian artery occluded, the anatomical variations of blood vessels about the shoulder and lateral chest wall, the degree of vasospasm associated with the occlusive process, the ability or inability of the collateral vessels to enlarge, the compression of collateral channels by oedema, and the possibility of thrombosis in the collateral pathways (Kinmonth, Simeone and Perlow, 1949 ; Shumacker, 1947). It is generally recognized that occlusion or ligation of the second part of the subclavian artery alone need cause no alarm or fear of subsequent gangrene in the arm. When this is associated with ligation of some or all of the branches of the subclavian artery, ischaemia and gangrene are more likely to occur. Indeed, it seems remarkable that more instances of gangrene are not observed after the Blalock procedure, considering how frequently it is necessary to ligate the subclavian branches to secure adequate mobilization of this artery.

In patients with coarctation of the aorta another factor must be considered. The prominent collateral circulation that develops to circumvent the site of stenosis is mediated chiefly through the subscapular and lateral thoracic to intercostal pathways. Is it not likely that, because this portion of the collateral pathway is already hypertrophied in a direction away from the arm, its potential for collaterality to the arm is diminished should this need become imminent? Such a possibility surely deserves consideration whenever sacrifice of the subclavian branches appears necessary in a patient with coarctation of the aorta.

The advent of homologous grafts, either freshly obtained or taken from blood vessel banks, will 
probably obviate the necessity for any type of subclavian anastomosis in patients with coarctation. In addition there is evidence to suggest that the blood flow made possible through a subclavian arterio-aortostomy does not justify its performance for repair of aortic coarctation (Clagett and Jampolis, 1951).

\section{SUMmaRY}

The case of an 18-year-old boy with the typical findings and history of an adult type aortic coarctation is presented. The coarctation was corrected by subclavian arterio-aortostomy. Postoperatively gangrene of the forearm developed necessitating amputation. The various factors involved are discussed briefly. This is believed to be the first such instance reported.

\section{REFERENCES}

Blalock, A. (1948). Surg. Gynec. Obstet., 87, 385.

and Park, E. A. (1944). Ann. Surg., $119,445$.

Clagett, O. T. (1947). Proc. Mayo Clin., 22, 131

and Jampolis, R. W. (1951). Arch. Surg., Chicago, 63, 337. Allaines, F. (1950). Chirurgie du Cour Paris. Cited by Webb and Burford (1952), v.i.

DeBakey, M. E., and Amspacher, W. H. (1949). Surg. Clin. N. Amer., 29, 1513.

Granström, K. O. (1951). Brit. J. Ophthal., 35, 143.

Gross, R. E. (1945). Surgery, 18, 673.

Hanlon, M. H., and Varco, R. (1952). Personal communication. Kinmonth, J. B., Simeone, F. A., and Perlow, V. (1949). Surgery.

26, 452. (1949). J. thorac. Surg., 18, 661.

Ram, C. R. (1949). J. thorac. Surg., 18, 661.

Shumacker, H. B., Jr. (1947). Surg. Gynec. Obstet., 84, 739.

(1951). Ibid., 93, 491.

Webb, W. R., and Burford, T. H. (1952). J. thorac. Surg., 23, 199. 